\title{
OIL SHALE ENERGETICS IN ESTONIA
}

Oil shale is not a new discovery for the world. Similar to coal, it can be used directly as a fuel. The role of oil shale in the energy production is unknown to most people because its contribution to today's world energy budget is minimal compared to such common known resources like petroleum and coal. However, the high price and declining petroleum supplies

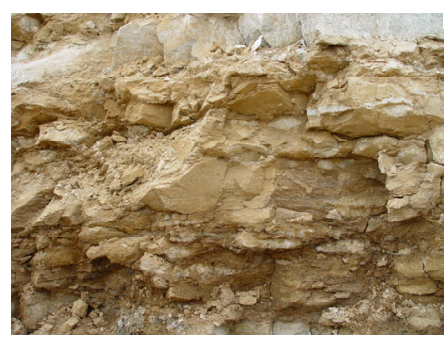
as well as rapidly increasing demand from the third world countries, is the reason why more frequent discussions about broader usage of oil shale are rising.

\section{A huge and almost unused resource}

Estimates of recoverable oil resources in the Earths crust amount to 160-170 billion tons. Considering the present annual output of 4 billion tons (whereas constant increase in use is not accounted) the explored resources can supply our needs for approximately 40 years.

Although information about many oil shale deposits is scarce, the potential world resources of shale oil are huge. Estimates of the volume of potential oil in the world oil shale deposits (so-called shale oil) range from 530 to 1430 billion tons (Fig. 1). This is $3-9$ times as much as the current proved oil reserves on the earth.

Fig. 1. Potential shale oil reserves and proved oil reserves (BP Statistical Review of World Energy, million tons)

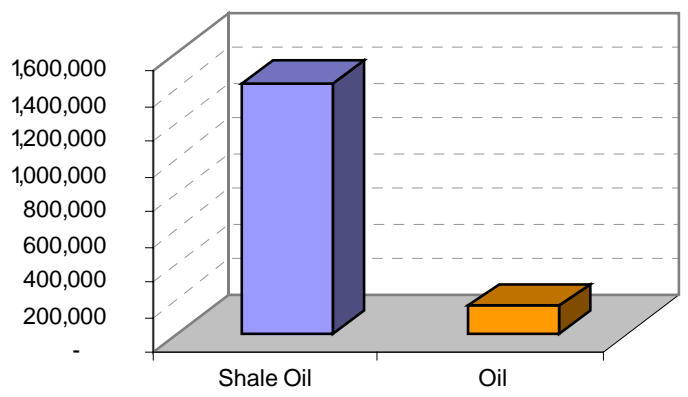

Oil shale occurs in many parts of the whole world, more than 600 deposits are known in more than 30 countries on all continents. The biggest shale oil resources are known in USA, Brazil, Jordan and Morocco. 
Table1. World percentage of oil shale resources (USDOE, 2005)

\begin{tabular}{l|c|l|c}
\hline Country & $\%$ & Country & $\%$ \\
\hline USA & 72 & China & 1.5 \\
Brazil & 5.4 & Estonia & 1.1 \\
Jordan & 4.2 & Israel & 0.3 \\
Morocco & 3.5 & Other & 10 \\
Australia & 2.1 & & \\
\hline
\end{tabular}

So far, the potential oil shale resources of the world have barely been touched but one is more than sure - oil shale represents a significant potential energy source for the future.

\section{Estonia's unique experience}

There is no other country in the world that can meet almost $80 \%$ of its electric power needs from oil shale. Most of the oil shale mined in Estonia today is utilized as a feedstock for production of energy. Approximately $20 \%$ of the shales are used for fuel oil production and chemical manufacturing.

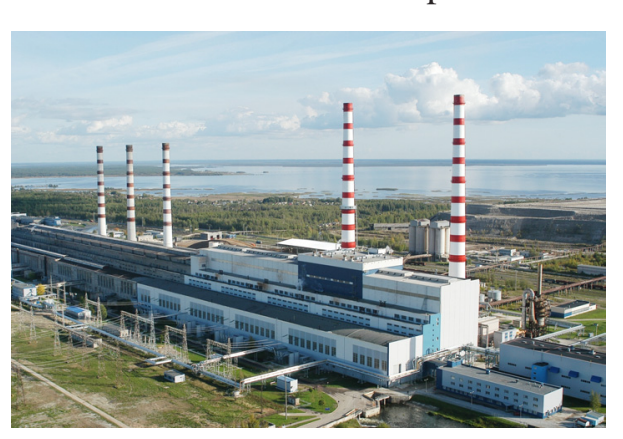

Eesti Energia AS (Estonian Energy) with its 500000 customers and more than 8000 employees is the leading Baltic energy utility as well as one of the biggest companies in Estonia. Eesti Energia generates 95\% of electric power produced in Estonia and has a yearly shale oil production of approx 130 thousand tons (Fig. 2).

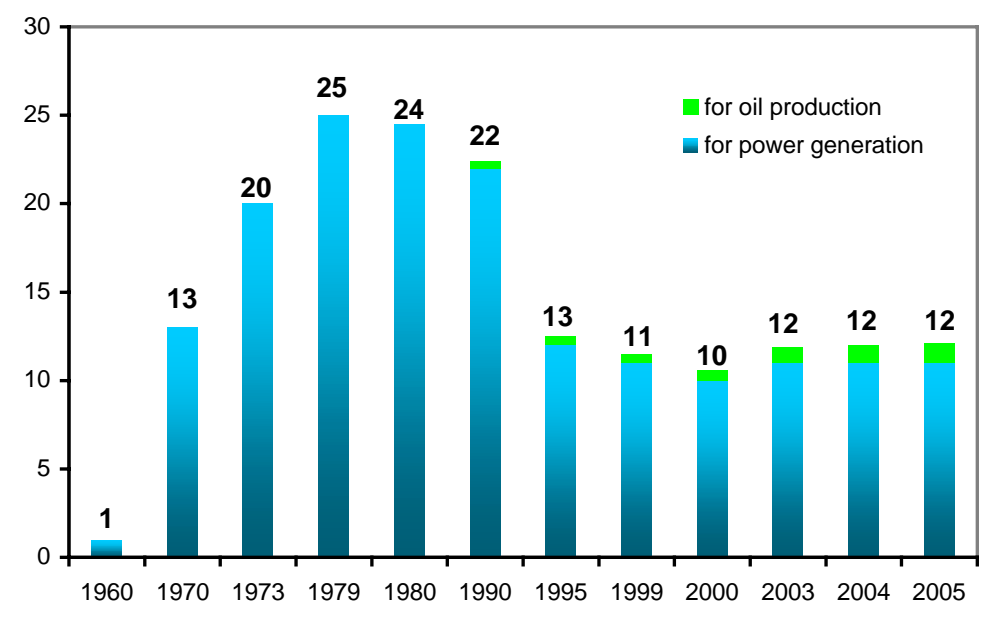

Fig. 2. Oil shale usage for power generation and oil production in Eesti Energia (in million tons) 
The introduction of the low-temperature CFB (circulating fluidized bed) boiler technology and the shale oil Galoter refinery process (solid heat carrier) for Estonian oil shale has been completely justified and the acquired positive experience serves as a solid foundation for ensuring the sustainability and competitiveness of the oil shale industry.

\section{New technology for power generation}

Eesti Energia owns the largest oil shale-fuelled power plants (Narva Power Plants) in the world burning about 11-12 million tons of oil shale yearly. Almost $95 \%$ of electric power of Estonia is produced from the shale.

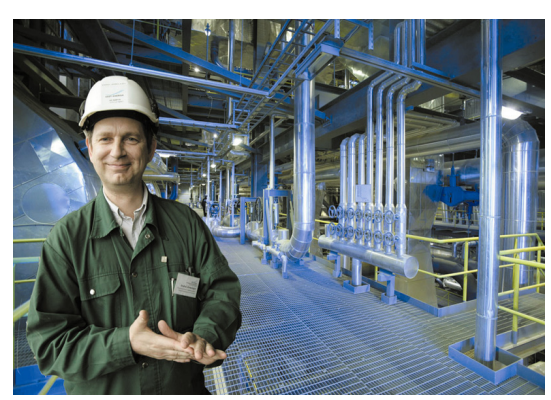

The new CFB boiler technology for electric power generation, in operation since 2004, has met expectations in all respects. Two $215 \mathrm{MW}$ power generating units have been switched to the new technology. Owing to that, the oil shale efficiency ratio has materially risen. About $1.4 \mathrm{~kg}$ of oil shale are burnt in older (pulverized combustion) Narva Power Plants boilers to generate $1 \mathrm{~kW}$ of electric power. Whereas measurements have revealed that the new technology has decreased the figure to $1.17 \mathrm{~kg}$ resulting in a substantial fuel saving.

The other positive effect is that the production performance and efficiency of boilers has risen such that a 20-percent fuel saving has been achieved. This will, in its turn, prolong the exploitation period for underground oil shale reserves. Furthermore, the percentage of harmful industrial contaminants emitted has substantially fallen and is now below Estonian and EU permissible limits.

\section{Oil Factory - unique technology for oil production}

The Narva Oil Factory exploits two unique TSK140 installations, which no other plant in the world can compete with. There is also a unique possibility for processing liquid and solid wastes and perished rubber into oil products.

The advantages of shale oil over heavy fuel oils are lower

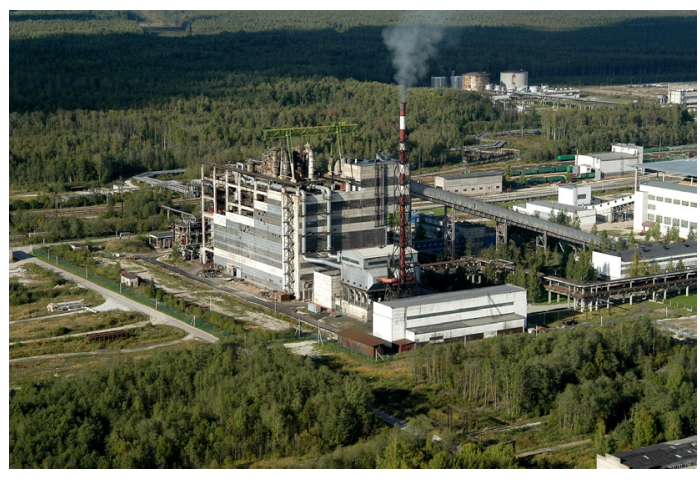
setting point, and lower content of sulphur and mechanical impurities, its low content of heavy metals, and the absence of vanadium. It is mostly used as fuel 
in both large and small boilers. The production of the Oil Factory amounted to 130,000 tons of shale oil in 2006.

The higher global prices of oil products in past years suggest that shale oil production will be increasingly profitable, and therefore a project for increasing the yearly production from 130,000 tons to 500,000 tons of shale oil is in progress. The plan is to expand shale oil production by erecting two new TSK 140 facilities as well as upgrading the current oil to a higher quality product. Of course the success of mentioned developments is very much dependent on the oil price of the world markets.

\section{Future outlook}

Eesti Energia is one of the few companies in the world which has a longlasting experience and know-how in oil shale mining and electricity and shale oil production using oil shale.

For power generation two new 300 MW CFB units at Narva Power Plants are planned and likely to be commissioned by 2012. In the light of more and more strict environmental regulations there are projects for producing wind energy and improving the ash removal process in progress. Part of the oil shale ash is also recycled as a valuable mineral-rich raw material, sold widely in the construction industry and farming.

The perspectives for shale oil production for coming years are quite ambitious:

$$
\begin{array}{ll}
- & \text { Increase of domestic production volumes } \\
- & \text { Upgrade of current products } \\
- & \text { Utilization of retorting gas in power production } \\
- & \text { Improvement of retorting technology } \\
- & \text { Development of international cooperation }
\end{array}
$$

Regarding international cooperation, on November 5th 2006 Oil Shale Energy of Jordan, a subsidiary of Eesti Energia, and the government of the Kingdom of Jordan concluded a memorandum of understanding, granting Eesti Energia's subsidiary the exclusive right to study about one third (300 million tonnes) of the resources of the El Lajjun oil shale deposit. The studies will take approximately 18 months. Tallinn University of Technology is also involved in the process because of its long experience and unique knowledge in this field.

To conclude, in the coming years more efficient power generation and increases in shale oil production as well as international cooperation in both fields are objectives of high strategic importance for Eesti Energia.

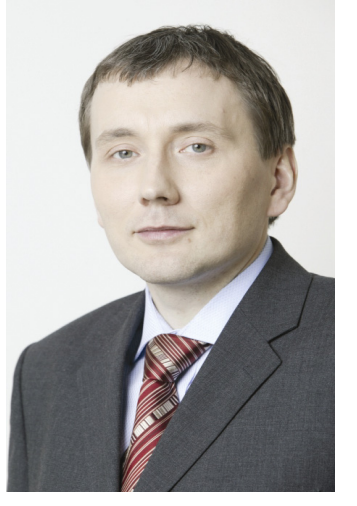

Sandor LIIVE Chairman of Eesti Energia Management Board 